\title{
OPTIMALISASI OTONOMI KHUSUS PAPUA DALAM PENINGKATAN KESADARAN HUKUM MASYARAKAT GUNA MEREDAM KONFLIK DAN KEKERASAN
}

\author{
Nur Rohim \\ Fakultas Syariah dan Hukum Universitas Islam Negeri Jakarta \\ E-mail: nurrohimyunus@gmail.com/087870535454
}

\begin{abstract}
Special autonomy has been given to the people of Papua was not automatically change the demand to break away from the Unitary Republic of Indonesia. Even conflict and violence are still common, not much the case in the period before the special autonomy granted. Legal awareness that should have been animating soul Indonesian citizens, to the condition of Papua away than they should. Disputes, inter-tribal warfare, even against migrants have often heard. The tribes in Papua does have a unique custom that sees itself as the center of the universe, the best of all. Papua leadership so very, very difficult to put together. Even if the idea is basically the idea Papuanisation fruit Dutch education is taught to the people of Papua to foster its own distinct sense of nationalism with the nation of Indonesia. The result appears separatist movements such as the Free Papua Organization (OPM) and the West Papua National Committee $(K N P B)$. To avoid the disintegration of the nation, the central government issued Law No. 21 of 2001 on Special Autonomy for Papua. That is, the people of Papua entitled to set its own country with the regulations stipulated by law. This legislation is expected to become a sedative from the turmoil in Papua. Although it remains to be an evaluation and improvements here and there. Such as optimizing the alignment of the central government towards the implementation of special autonomy, optimizing the role of the Papuan People's Assembly, and optimization of special autonomy fund supervision. So that the common goal of creating prosperity, welfare and peace of Indonesian citizens in Papua indigenous ancestral lands can be realized.
\end{abstract}

Keywords: Special Autonomy, Law Awareness, Conflict and Violence

\section{abstrak}

Otonomi Khusus yang telah diberikan kepada rakyat Papua ternyata tidak secara otomatis mengubah tuntutan melepaskan diri dari Negara Kesatuan Republik Indonesia. Bahkan konflik dan kekerasan masih sering terjadi, tidak jauh halnya pada masa sebelum otonomi khusus diberikan. Kesadaran 
Hukum yang seharusnya sudah menjiwai jiwa raga warga negara Indonesia, untuk kondisi Papua jauh dari yang seharusnya. Pertikaian, peperangan antar suku, bahkan melawan warga pendatang sudah sering terdengar. Suku-suku yang ada di Papua memang memiliki kebiasaan unik yang memandang dirinya sebagai pusat dari semesta, terbaik dari semua. Sehingga kepemimpinan Papua amat sangat sulit untuk disatukan. Kalaupun muncul ide gagasan Papuanisasi pada dasarnya merupakan buah pendidikan Belanda yang diajarkan kepada masyarakat Papua untuk menumbuhkan rasa nasionalisme tersendiri yang berbeda dengan bangsa Indonesia. Akibatnya muncul gerakan separatisme seperti Organisasi Papua Merdeka (OPM) dan Komite Nasional Papua Barat (KNPB). Untuk menghindari adanya disintegrasi bangsa, Pemerintah Pusat mengeluarkan Undang-Undang No. 21 Tahun 2001 tentang Otonomi Khusus Papua. Artinya, masyarakat Papua berhak mengatur daerahnya sendiri dengan ketentuan yang diatur dengan undang-undang. Diharapkan undang-undang ini mampu menjadi obat penenang dari gejolak yang terjadi di Papua. Walaupun masih tetap harus diadakan evaluasi dan perbaikan di sana sini. Seperti optimalisasi keberpihakan pemerintah pusat terhadap pelaksanaan otonomi khusus, optimalisasi peran Majelis Rakyat Papua, dan optimalisasi pengawasan dana otonomi khusus. Sehingga tujuan bersama untuk menciptakan kemakmuran, kesejahteraan dan kedamaian warga negara Indonesia asli Papua di tanah leluhurnya dapat terwujud.

\section{Kata Kunci: Otonomi Khusus, Kesadaran Hukum, Konflik dan Kekerasan}

\section{A. Pendahuluan}

Pemerintah daerah berwenang untuk mengatur dan mengurus sendiri urusan pemerintahan menurut asas otonomi daerah sebagaimana yang diamanatkan dalam Undang-Undang Dasar Republik Indonesia 1945. Hal tersebut diarahkan untuk mempercepat terwujudnya kesejahteraan masyarakat daerah melalui peningkatan pelayanan, pemberdayaan, dan peran serta masyarakat, serta peningkatan daya saing daerah dengan memperhatikan prinsip demokrasi, pemerataan, keadilan, keistimewaan, dan kekhususan suatu daerah dalam Negara Kesatuan Republik Indonesia. Negara Indonesia, dijelaskan dalam pasal 18B ayat 1 UUD 1945, mengakui dan menghormati satuan-satuan pemerintahan daerah yang bersifat khusus atau bersifat istimewa.

Provinsi Papua adalah Provinsi Irian Jaya ${ }^{1}$ yang merupakan bagian dari wilayah Negara Kesatuan Republik Indonesia, yang memiliki

\footnotetext{
${ }^{1}$ Sebelum reformasi, kawasan yang berupa bagian barat dari Pulau Papua ini -karena sebelah timur adalah Negara Papua New Guinea - bernama Irian Jaya, sebuah nama yang dipilih
} 
keragaman suku dan lebih dari 250 (dua ratus lima puluh) bahasa daerah serta dihuni juga oleh suku-suku lain di Indonesia. ${ }^{2}$ Keputusan politik penyatuan Papua menjadi bagian dari Negara Kesatuan Republik Indonesia pada hakikatnya mengandung cita-cita luhur. Namun kenyataannya berbagai kebijakan dalam penyelenggaraan pemerintahan dan pembangunan yang sentralistik belum sepenuhnya memenuhi rasa keadilan, belum sepenuhnya memungkinkan tercapainya kesejahteraan rakyat, belum sepenuhnya mendukung terwujudnya penegakan hukum, dan belum sepenuhnya menampakan penghormatan terhadap Hak Asasi Manusia (HAM) di Provinsi Papua, khususnya masyarakat Papua. Kondisi tersebut mengakibatkan terjadinya kesenjangan pada hampir semua sektor kehidupan, terutama dalam bidang pendidikan, kesehatan, ekonomi, kebudayaan, dan sosial politik.

Pelanggaran HAM, pengabaian hak-hak dasar penduduk asli dan adanya perbedaan pendapat mengenai sejarah penyatuan Papua ke dalam Negara Kesatuan Republik Indonesia adalah masalah-masalah yang perlu diselesaikan. Upaya penyelesaian masalah tersebut selama ini dinilai kurang menyentuh akar masalah dan aspirasi masyarakat Papua, sehingga memicu berbagai bentuk kekecewaan dan ketidakpuasan.

Hingga akhirnya lahirnya UU No. 21 Tahun 2001 tentang Otonomi Khusus Bagi Papua yang merupakan komitmen pemerintah dan seluruh rakyat Indonesia untuk mengadopsi perspektif baru dalam menangani berbagai permasalahan yang mewarnai kehidupan Provinsi Papua. Perspektif baru tersebut adalah melakukan perubahan pendekatan penanganan masalah

oleh Pemerintah Indonesia setelah kawasan ini resmi menjadi bagian dari Republik Indonesia pada 1 Mei 1962, melalui negosiasi yang alot dan sengit di forum Internasional. Nama "Irian" diperkenalkan pada Konferensi Malino pada tahun 1946. Dalam bahasa Biak, kata itu berarti "sinar matahari menghalau kabut di laut". Presiden Soekarno menjadi penganjur utama penggunaan nama Irian, dengan mengakronimkan IRIAN sebagai "Ikut Republik Indonesia Anti Nederland" .Koentjaraningrat, Irian Jaya: Membangun Masyarakat Majemuk, (Jakarta: Djambatan, 1993), hlm. 3-5.

2 Wilayah Provinsi Papua pada saat ini terdiri atas 12 Kabupaten dan dua Kota, yaitu: Kabupaten Jayapura, Kabupaten Merauke, Kabupaten Biak Numfor, Kabupaten Mimika, Kabupaten Jayawijaya, Kabupaten Puncak Jaya, Kabupaten Paniai, Kabupaten Nabire, Kabupaten Sorong, Kabupaten Fakfak, Kabupaten Yapen Waropen, Kabupaten Manokwari, Kota Jayapura, dan Kota Sorong. Provinsi Papua memiliki luas kurang lebih 421.981 km2 dengan topografi yang bervariasi, mulai dari dataran rendah yang ber-rawa sampai dengan pegunungan yang puncaknya diselimuti salju. Wilayah Provinsi Papua berbatasan di sebelah utara dengan Samudera Pasifik, di sebelah selatan dengan Provinsi Maluku dan Laut Arafura, di sebelah barat dengan Provinsi Maluku dan Maluku Utara, dan di sebelah timur dengan Negara Papua New Guinea. 
di Papua dari pendekatan keamanan/stabilitas menjadi pendekatan sosial/kesejahteraan. ${ }^{3}$

Permasalahan-permasalahan yang ada belum sepenuhnya dapat tertangani hingga masa otonomi khusus di wilayah papua. Permasalahanpermasalahan yang timbul menimbulkan konflik dan sengketa yang tentunya menghambat upaya suksesi otonomi khusus di Papua. Oleh karenanya timbul pertanyaan untuk sekiranya penulis analisis. Pertama; sejauh mana upaya pemerintah pusat mengoptimalisasikan otonomi khusus di Papua? Kedua; apa model sengketa dan solusi peningkatan kesadaran hukum masyarakat papua terhadap permasalahan yang ada?

\section{B. Metode Penelitian}

Penelitian ini merupakan penelitian deskriptif, yaitu merupakan prosedur pemecahan masalah yang diselidiki dengan menggambarkan atau melukiskan keadaan subjek atau objek seseorang, lembaga, masyarakat, dan lain-lain pada saat sekarang, berdasarkan fakta-fakta yang tampak dan sebagaimana adanya. Data yang digunakan adalah data kualitatif, ${ }^{4}$ yaitu data atau informasi yang bersifat sewajarnya mengenai suatu masalah dalam kondisi aspek atau bidang kehidupan tertentu pada objeknya. Data berupa keterangan-keterangan dikumpulkan lewat observasi, penelusuran literatur, dokumen, peraturan perundang-undangan, dan lain sebagainya.

Teknik pengumpulan data yang dilakukan adalah pengumpulan data primer dan sekunder. Data sekunder digunakan untuk data pendukung yang dibutuhkan untuk melengkapi data primer, dapat berupa konsep/literatur, kebijakan, berita media massa, hasil kajian-kajian yang terkait, dan laporanlaporan seperti: Provinsi, Kabupaten/Kota dalam angka yang biasanya disajikan oleh Bappeda Kabupaten dan Kota/Badan Pusat Statistik, Data/Laporan Hasil EKPPD, LAKIP, Laporan Penyelenggaraan Pemerintah Daerah Tahunan, APBD Provinsi Papua dan data-data lainnya yang digunakan untuk menganalisa dan menggambarkan bagaimana pencapaian pembangunan Papua dan Papua Barat pada masa pelaksanaan otonomi khusus dan juga bagaimana kebijakan terimplementasikan di daerah tersebut.

\section{Pembahasan}

Beberapa permasalahan yang sekiranya menjadi fokus pembahasan dan analisis dalam jurnal ini di antaranya yaitu:

\footnotetext{
${ }^{3}$ Mohammad A. Musa'ad, "Kontekstualisasi Pelaksanaan Otonomi Khusus di Provinsi Papua: Perspektif Struktur dan Kewenangan Pemerintahan”, Jurnal Kajian, Vol. 16, No. 2, Juni 2011, (Jakarta: Sekretariat Jenderal DPR RI, 2011), hlm. 359.

${ }^{4}$ Hadari Nawawi, Metode Penelitian Ilmiah, (Jakarta: Rineka Cipta, 1994), hlm. 176.
} 


\section{Asal Nama dan Kultur Papua}

Sebelum diberi nama "Irian Jaya", 5 kawasan ini dikenal dengan nama "Papua". Nama "Papua" pada awalnya dipergunakan oleh pelaut Portugis Antonio d'Arbrau, yang mendarat di pulau ini pada tahun 1521. Diperkirakan, kata "Papua" berasal dari kata dalam bahasa Melayu kuno "pua-pua", yang berarti "keriting". Nama ini kemudian dipakai oleh Antonio Pigafetta yang ikut dalam pelayaran dengan Ferdinand Magellan mengelilingi bumi.

Versi lain dari penamaan Papua adalah dari Papua bagian Timur, kini menjadi Papua Nieuw Guinea. Sebutan "Nieuw Guinea" digunakan oleh para pelaut Belanda, menggunakan penamaan dari seorang pelaut Spanyol, Ynigo Ortiz de Retes, yang mengunjungi kawasan utara pulau ini pada tahun 1545. Dinamakan "Nieuw Guinea" karena penduduk yang ditemui berwarna hitam, seperti penduduk di Pantai Guinea, Afrika.

Papua mempunyai kondisi sosial-budaya-politik yang khas. Ciri-ciri fisiologi Tanah Papua yang beragam menyebabkan diferensiasi sistem mata pencaharian. Bukan hanya itu, perkembangan struktur sosial masyarakat juga turut dipengaruhi oleh proses-proses adaptasi manusia terhadap lingkungan alam. Sifat kemajemukan penduduk Papua juga dapat dilihat dari prinsip hak ulayat tanah. Di antara masyarakat Papua terdapat kolektifkolektif etnik yang mengatur sistem hak ulatnya melalui klan (merupakan hak komunal). Selain itu terdapat pula kolektif-kolektif lain yang mengatur hak ulayatnya melalui keluarga inti atau hak individu.

M.T. Walker dan J.R. Mansoben ${ }^{6}$ mencatat bahwa keanekaragaman orang Papua bertalian erat dengan pola adaptasi sosio-ekonomi penduduk pada zona ekologi utama. Setidaknya ada empat zona ekologi utama. Pertama, ekologi rawa, daerah pantai, dan muara sungai; kedua, dataran pantai; ketiga, kaki gunung dan lembah-lembah kecil; dan keempat pegunungan tinggi. Lingkungan ekologi yang berpengaruh terhadap polapola adaptasi tercermin dalam sistem mata pencaharian hidup meliputi teknologi dan sistem pembagian kerja. Semakin kompleks inovasi teknologi

\footnotetext{
${ }^{5}$ Provinsi Irian Jaya adalah perubahan dari nama Irian Barat yang dilakukan oleh Presiden Soeharto tahun 1973, dan kemudian diganti menjadi Papua tahun 2000 dibawah Presiden Abdurrahman Wahid untuk menanggapi tuntutan para nasionalis Papua. Di Tahun 2003, Provinsi Irian jaya Barat, yang kemudian diubah menjadi Papua Barat dibentuk. Banyak nasionalis menggunakan istilah West Papua atau Papua Barat untuk menyebut seluruh bekas daerah jajahan Belanda West New Guinea (Nugini Barat). Istilah lain yang tidak mengandung muatan politik yang kadan dipakai untuk menyebut daerah ini yaitu "Tanah Papua”, dan tidak punya makna hukum apa-apa. [Lihat: Asia Report N 232, Indonesia, Dinamika Kekerasan di Papua, (Jakarta: International Crisis Group, 2012), hlm.4.

${ }^{6}$ Agung Djojosoekarto, dk, Kinerja Otonomi Khusus, (Jakarta: Kemitraan, 2008), hlm. 6.
} 
dan sistem pembagian kerja, maka aspek budaya lain seperti organisasi sosial dan sistem ideologi (ritual agama) juga kian rumit.

Di zona ekologi pegunungan tengah, misalnya, masyarakat hidup dalam rumah-rumah besar dalam hubungan keluarga yang luas, dengan jaringan luas dari sistem klan, gabungan klan, dan federasi yang kompleks. Contoh penduduk yang menganut pola ini adalah suku Dani. Tipe ini menghasilkan ikatan horizontal yang kuat. Pada zona ekologi muara sungai, kepulauan dan pesisir pantai, penduduk hidup dalam keluarga-keluarga inti kecil yang amat bersifat individualis. Karena wilayah pesisir dan kepulauan relatif sulit dijadikan lahan pertanian, untuk memenuhi kebutuhan hidupnya, mendorong mereka untuk berdagang. Contoh masyarakat ini adalah penduduk pantai utara.

Kedua tipe ini menghasilkan relasi yang berbeda sehingga berpengaruh terhadap ikatan kolektif yang terbentuk. Di sinilah kemudian makna keluarga mendapat tempat dalam struktur hierarki masyarakat. Di satu sisi, keluarga mempunyai fungsi produktif, di sisi lain keluarga merupakan identitas untuk sarana reproduksi kekuasaan. Aktifitas perang lantas menjadi bagian dari persaingan produksi, sedangkan perkawinan sebagai sarana reproduksi kekuasaan. Tidak mengherankan jika ritual ini menyedot konsumsi besar untuk keperluan pesta adat. Kebutuhan pesta adat inilah yang di kemudian hari memberikan porsi bagi munculnya pola patronklien dimana patron merupakan pihak yang mensponsori pesta.

\section{Otonomi Khusus Papua}

Keinginan politik (political will) Pemerintah Indonesia untuk menangani Papua secara sungguh-sungguh dimulai sejak tahun $1999,{ }^{7}$ yang ditandai dengan pemberian nama Papua menggantikan Irian Jaya oleh Presiden Abdurrahman Wahid dan memperbolehkan mengibarkan bendera bintang kejora sebagai simbol kebudayaan orang Papua dan bukan untuk memisahkan diri dari Negara Kesatuan Republik Indonesia (NKRI). ${ }^{8}$

Hal ini dirasakan penting karena dianggap sebagai bagian dari pengembangan jati diri orang Papua yang seutuhnya yang ditunjukan dengan penegasan identitas dan harga dirinya termasuk dengan dimilikinya simbol-

\footnotetext{
${ }^{7}$ Pada masa Orde Baru Pasca Pepera, penanganan Papua dinilai masih setengah hati, bahkan cenderung hanya penguasaan pusat terhadap wilayah strategis Papua. Sehingga menimbulkan gejolak dan polemik yang berkepanjangan. Kekerasan dan pembunuhan hampir mewarnai kehidupan sehari-hari masyarakat Papua. Masyarakat Papua dihadapkan pada dua pilihan yang tidak harus dipilih, karena kedua-duanya mengancam keselamatan jiwa dan harta mereka, yaitu moncong senapan TNI di depan, serta panah dan tombak militan OPM di belakang.

${ }^{8}$ M. Ridha Saleh, "Saudara Presiden, Datanglah ke Papua, Kompas, 3 November 2011, hlm. 6.
} 
simbol daerah seperti lagu, bendera, dan lambang. Selain itu, Pemerintah juga menetapkan Provinsi Irian Jaya sebagai daerah otonomi khusus, yang secara eksplisit tertuang dalam Ketetapan MPR RI Nomor IV/MPR/1999 tentang Garis-Garis Besar Haluan Negara Tahun 1999-2004, Bab IV huruf G, butir 2. Menindaklanjuti amanat Tap MPR tersebut, DPR pada tanggal 22 Oktober 2001 telah menyetujui dan menetapkan Undang-Undang tentang Otonomi Khusus bagi Provinsi Papua. Keputusan DPR tersebut disahkan pada tanggal 21 November 2001 sebagai UU No. 21 Tahun 2001 tentang Otonomi Khusus bagi Provinsi Papua, Lembaran Negara Republik Indonesia Tahun 2001 Nomor 135. ${ }^{9}$

Kehadiran UU No. 21 Tahun 2001 merupakan upaya perjuangan karena pada saat itu harus diyakinkan segenap komponen masyarakat Papua, khususnya orang asli Papua, yang ketika itu menyuarakan M (baca: memisahkan diri dari NKRI) ${ }^{10}$ bahwa Otsus merupakan pilihan yang paling tepat. Tidak berhenti sampai di situ, dalam pembahasan RUU Otsus Papua di DPR juga terdapat upaya perjuangan. Sebab, RUU yang merupakan usul inisiatif DPR tersebut mendapat masukan dari Pemerintah dalam bentuk Daftar Inventarisasi Masalah (DIM) sebanyak 471 masalah. Perjuangan meloloskan UU No. 21 Tahun 2001 pada waktu itu juga ditambah dengan kasus tewasnya Ketua Presidium Dewan Papua Theys Hiyo Eluay, beberapa hari sebelum Presiden Megawati Soekarnoputri menerbitkan UU No. 21 Tahun 2001. ${ }^{11}$

Pada dasarnya istilah "otonomi" dalam Otonomi Khusus diartikan sebagai kebebasan bagi rakyat Papua untuk mengatur dan mengurus diri sendiri, sekaligus pula berarti kebebasan untuk melaksanakan pemerintahan sendiri dan mengatur pemanfaatan kekayaan alam Papua untuk sebesarbesarnya kemakmuran rakyat Papua dengan tidak meninggalkan tanggungjawab untuk ikut serta mendukung penyelenggaraan pemerintahan pusat dan daerah-daerah lain di Indonesia yang memang kekurangan. Hal lain yang tidak kalah penting adalah kebebasan untuk menentukan strategi pembangunan sosial, budaya, ekonomi, dan politik yang sesuai dengan karakteristik dan kekhasan sumberdaya manusia serta kondisi alam dan kebudayaan orang Papua.

Selain menyelenggarakan pemerintahan dan mengatur pemanfaatan kekayaan alam di Provinsi Papua untuk sebesar-besarnya bagi kemakmuran rakyat Papua sebagai bagian dari rakyat Indonesia sesuai dengan peraturan perundang-undangan. Kewenangan ini berarti pula kewenangan untuk memberdayakan potensi sosial-budaya dan perekonomian masyarakat Papua,

\footnotetext{
${ }^{9}$ Mohammad A. Musa'ad, op.cit., hlm. 359-360.

${ }^{10}$ Ibid, Istilah ini juga masih sering dilontarkan dalam wawancara dengan beberapa anggota DPRP dan anggota MRP untuk menyatakan M=MERDEKA.

11 “Membangun Papua: Dari Otsus “Terbitlah” UP4B, Kompas, 4 November 2011, hlm. 46.
} 
termasuk memberikan peran yang memadai bagi orang-orang asli Papua melalui para wakil adat, agama, dan kaum perempuan. Peran yang dilakukan adalah ikut serta merumuskan kebijakan daerah, menentukan strategi pembangunan dengan tetap menghargai kesetaraan dan keragaman kehidupan masyarakat Papua, melestarikan budaya serta lingkungan alam Papua, yang tercermin melalui perubahan nama Irian Jaya menjadi Papua, lambang daerah dalam bentuk bendera daerah dan lagu daerah sebagai bentuk aktualisasi jati diri rakyat Papua dan pengakuan terhadap eksistensi hak ulayat, adat, masyarakat adat, dan hukum adat.

Sedang istilah "khusus" lebih diartikan sebagai perlakuan berbeda yang diberikan kepada Papua karena kekhususan yang dimilikinya. Kekhususan tersebut mencakup hal-hal seperti tingkat sosial ekonomi masyarakat, kebudayaan, dan sejarah politik. Dalam pengertian praktisnya, kekhususnya otonomi Papua berarti bahwa ada hal-hal berdasar yang hanya berlaku di Papua dan tidak berlaku di daerah lain di Indonesia, dan ada halhal yang berlaku di daerah lain yang tidak diterapkan di Papua.

Otonomi Khusus (Otsus) oleh berbagai kalangan selama ini dianggap titik kunci penting untuk menetapkan status politik, baik bagi pemerintah maupun masyarakat Papua. Sebagaimana diketahui, melalui Undang-undang Nomor 21 Tahun 2001 tentang Otonomi Khusus, Papua telah diberi kewenangan untuk mengatur pemerintahan sendiri berdasarkan peraturan perundangan. Dengan Otonomi Khusus, pemerintah pusat menghendaki agar gerakan-gerakan separatis dapat segera menghentikan aktivitasnya, dan Papua tetap menjadi bagian dari Negara Kesatuan Republik Indonesia (NKRI). Implikasi lebih lanjut adalah bahwa perdamaian di Papua akan terus terjaga, tanpa ada pergolakan politik yang ingin memerdekakan diri.

Pemberlakuan Otonomi Khusus bagi Provinsi Papua sedikit banyak telah dapat menjadikan obat penenang bagi masyarakat Papua. Selama hampir 27 tahun, sejak Pepera diadakan PBB, masyarakat Papua hidup dalam tekanan dari kekangan pemerintah pusat yang menggunakan pendekatan keamanan dalam menjaga integrasi wilayah yang penuh sumber daya alam tersebut. Semasa pemerintahan Presiden Abdurahman Wahid, rancangan UU Otonomi Khusus Papua digodog, dan ketika masa Presiden Megawati Undang-undang itu disahkan, meskipun pada kenyataannya implementasi di lapangan masih belum maksimal.

Salah satu tuntutan paling kuat dari aspirasi yang berkembang di Papua pada tahun 2003 adalah tuntutan pembentukan Majelis Rakyat Papua (MRP). ${ }^{12}$ Selain tuntutan Kepala Daerah berasal dari orang asli Papua,

12 Sebagaimana diatur dalam UU Otsus Papua tersebut, Pasal 19 menyebutkan: (1) MRP beranggotakan orang-orang asli Papua yang terdiri atas wakil-wakil adat, wakil-wakil agama, dan wakil-wakil perempuan yang jumlahnya masing-masing sepertiga dari total anggota MRP; (2) Masa keanggotaan MRP adalah 5 (lima) tahun; (3) Keanggotaan dan 
pengelolaan secara maksimal Sumber Daya Alam Papua untuk masyarakat Papua, dan beberapa hal penting lainnya.

Pemekaran distrik (kecamatan) dan kabupaten sesuai dengan UU Otonomi Khusus merupakan salah satu alternatif solusi bagi Papua. Pemekaran tersebut merupakan upaya melaksanakan aspirasi masyarakat bawah Papua. Sebagian besar masyarakat berpendapat bahwa pemekaran provinsi Papua sebagaimana dalam Inpres No. 1 tahun 2003 tentang Percepatan Pembangunan di Papua menjadi 3 provinsi, bukanlah suatu hal yang efektif. Alasannya bahwa sumber daya manusia yang ada di Papua belum dapat untuk mengendalikannya.

\section{Akar Konflik Papua}

Masyarakat Papua merupakan suatu entitas yang heterogen. Kepapuaan baru dibangun secara terbatas bersamaan dengan tumbuhnya lapisan kecil elit terdidik melalui Sekolah Pamong Praja yang didirikan oleh Pemerintah Belanda pada 1940-an. Di sana pendidikan administrasi pemerintahan dijalani. Pada kesempatan itu para pelajar Papua banyak berdiskusi tentang persoalan kepapuaan dan kemungkinan Papua Barat menjadi satu negara bangsa yang merdeka. Pada awal 1960-an sudah disiapkan bendera nasional, lagu kebangsaan, dan lambang negara. Pada 1 Desember 1961 dengan bantuan Belanda diproklamasikan Negara Papua Barat. ${ }^{13}$ Dari sini bibit nasionalisme Papua mulai tersemaikan.

Reaksi Pemerintah Republik Indonesia dan perkembangan politik berikutnya membuat Papua Barat kemudian diintegrasikan dengan RI. Identitas dan nasionalisme Papua terkubur sementara bersamaan dengan penggantian nama Papua Barat menjadi Irian Barat dan integrasi kehidupan sosial politik ekonomi dan kebudayaan Papua di bawah administrasi Negara Kesatuan Republik Indonesia. Belasan tahun kemudian, tepatnya sejak 1978, melalui kesenian identitas Papua pernah dibangun kembali oleh kelompok Mambesak Arnold Ap. Namun kepapuaan kembali terhambat karena Arnold Ap kemudian dipenjara oleh pemerintah RI di bawah Orde Baru. ${ }^{14}$

Pada era reformasi, pada kurun 1998-1999, kepapuaan kembali dihidupkan sebagai identitas alternatif dari identitas "Irian Jaya" yang telah identik dengan Indonesia beserta adanya anggapan penindasan dan praktek

jumlah anggota MRP ditetapkan dengan Perdasus; dan (4) Kedudukan keuangan MRP ditetapkan dengan Peraturan Pemerintah. [Lihat: Indra J. Piliang, Otonomi Khusus Papua dan MRP, Suara Pembaruan, 11 Juli 2003].

${ }^{13}$ Decki Natalis Pigay, Evolusi Nasionalisme dan Sejarah Konflik Politik di Papua, (Jakarta: Sinar Harapan, 2000), hlm. 285.

${ }^{14}$ Menurut analisis pemerhati Papua di manca negara Arnold Ap kemudian dibunuh melalui suatu konspirasi yang melibatkan Kopassandha. [Lihat: Carmel Budiardjo dan Liem Soei Liong, West Papua: The Obliteration of a People, (London: Tapol) hlm. 125-136. 
kolonialismenya. Perasaan satu identitas ini disatukan oleh memori penderitaan kolektif dan kongruensi aspirasi yang bersumber dari mitologi sebagian besar suku bangsa masing-masing tentang milenium baru dan mesianisme. Pada era reformasi penggunaan nama Papua menjadi penanda bagi aspirasi bersama itu. Kongruensi aspirasi dan identitas kepapuaan baru pada tahap yang sangat dini. Kepapuaan cenderung berhenti sebagai identitas yang dihayati secara "etnosentris" dan emosional.

\section{Model Kekerasan di Papua}

Serangkaian kekerasan kerap terjadi di Papua pada masa Orde Baru hingga masa reformasi, bahkan pasca dilegislasinya Undang-Undang Nomor 21 Tahun 2001 tentang Otonomi Khusus Papua. Peristiwa penembakan terhadap warga Non-Papua, atau terhadap tentara militer, atau sebaliknya, sudah menjadi hal lumrah pada kehidupan masyarakat Papua. Kesadaran hukum masyarakat memang masih teramat rendah. Hal ini tentunya bukan karena tanpa faktor yang melatarbelakanginya. Ada penyebab yang menjadi faktor utama dan faktor penunjang terjadinya kekerasan tersebut.

Faktor utama yang mendorong terjadi kekerasan di Papua adalah: Pertama, adanya ketidakpuasan yang dirasakan oleh masyarakat Papua terhadap pemerintah pusat. Kedua, adanya aspek dari kebijakan keamanan yang bertentangan dengan niat pemerintah untuk membangun kepercayaan, mempercepat pembangunan, dan merealisasikan tujuan dari UU No. 21 tahun 2001 tentang Otonomi Khusus bagi Provinsi Papua. ${ }^{15}$

Adapun faktor penunjang lain yang menjadi penyebab terjadinya kekerasan pada masyarakat papua di antaranya, yaitu:

\section{a. Kebiasaan Perang Antar Suku}

Kekuatan orang Papua pada umumnya adalah kemampuan negosiasi di dalam konflik antar kelompok. Institusi resolusi konflik secara tradisional berkembang dan digunakan untuk mengakhiri suatu krisis hubungan antar kelompok. Tradisi negosiasi, terutama di kalangan orang pegunungan, digunakan untuk menyelesaikan kasus-kasus pembunuhan, perzinaan, pencurian, dan lain-lain. Perang suku atau jalan kekerasan baru diambil ketika negosiasi mengalami kebuntuan atau pihak yang bertikai memang secara kultural merupakan "musuh" permanen. Hanya saja mekanisme ini

\footnotetext{
${ }^{15}$ Sebagai evaluasi, hingga saat ini UU Otsus belum menghasilkan manfaat yang nyata bagi kehidupan sebagian besar masyarakat dan belum memperbaiki hubungan antara Papua dengan Pemerintah Pusat. Substansinya selama ini kerap diperlemah oleh Jakarta, meskipun para anggota DPRP juga bertanggungjawab karena gagal menetapkan peraturan-peraturan pelaksana yang diperlukan. [Lihat: Asia Report N 232, Indonesia, Dinamika Kekerasan di Papua, (Jakarta: International Crisis Group, 2012), hlm.i].
} 
hanya berlaku di dalam intern kelompok suku. Di dalam konflik antar suku kecenderungan untuk mengambil jalan kekerasan masih sangat kuat.

Perang suku adalah habitus tradisional yang secara mental belum sepenuhnya hilang pada sebagian rakyat Papua. Kekerasan ditempatkan menjadi bagian inheren di dalam ritual dan hukum adat tertinggi untuk suatu resolusi konflik. Ini menjadikan kekerasan sebagai bagian dari pilihanpilihan tindakan yang dianggap sah dan dalam momen tertentu dianggap "sakral". Provokasi pihak lain atau pun pihak internal suku yang memanipulasi terminologi setempat dan menyentuh mods kelompok akan dengan mudah menghadirkan kekerasan baru.

Kebiasaan melakukan perang dalam hal ini dapat diartikan dengan kebiasaan untuk melakukan kekerasan. Sehingga, kebiasaan yang dilakukan terhadap musuh suku juga diberlakukan terhadap para pendatang (nonpapua), termasuk juga aparat pemerintah pusat.

\section{b. Kepemimpinan Papua yang Sulit Menyatu}

Struktur-struktur masyarakat Papua yang terdiri dari kurang lebih 250 suku bangsa bersifat otonom satu sama lain. Setiap kelompok suku secara kultural mandiri dan unik, tidak tunduk pada kelompok suku yang lain, dan setiap suku memiliki kosmologi yang memandang dirinya sebagai pusat dari semesta. Setiap kepala suku atau pemimpin lokal tidak memiliki otoritas yang penuh kecuali sebagai juru bicara masyarakatnya. Interaksi yang terbatas di masa lalu belum memungkinkan tumbuhnya kesadaran budaya yang relativistik dan toleran. Oleh karena itu etnosentrisme menjadi persoalan dasar di dalam konsolidasi rakyat Papua. Di dalam kenyataan budaya semacam ini sulit tumbuh suatu kepemimpinan yang diakui oleh semua kelompok suku bangsa. ${ }^{16}$

Kesulitan mengakui satu pemimpin ini lebih dipengaruhi oleh arogansi masing-masing suku yang menganggap sebagai suku yang terbaik. Sehingga perbedaan yang berakibat kepada konflik tidak pernah berhenti, bahkan kerap berlanjut. Artinya, masyarakat Papua akan sulit untuk dapat bersatu dalam satu kesatuan. Kalau pun ada kesadaran bersama untuk mengakui kesamaan bangsa sebagai bangsa Papua, itu pun lahir sejak penguasaan dan didikan belanda untuk menjadikan Papua sebagai Negara Merdeka.

\footnotetext{
${ }^{16}$ Bandingkan dengan studi yang sudah dilakukan oleh Johszua Mansoben, Sistem Politik Tradisional di Irian Jaya, (Jakarta-Leiden: LIPI-RUL).
} 


\section{c. Stigma Gerakan Separatis OPM}

Organisasi Papua Merdeka lahir setelah serangkaian pertarungan kekuasaan yang melibatkan Pemerintah RI, Amerika Serikat, UNTEA (United Nations Temporary Executive Authority), Pemerintah Belanda, dan sejumlah elit terdidik Papua yang berlangsung sejak 1962 hingga 1969. Pemungutan Pendapat Rakyat (Pepera atau Act of Free Choice) pada 1969 menandai "kemenangan" usaha integrasi Papua Barat oleh Pemerintah RI. Sebagian elit Papua yang Pro Belanda hijrah ke Belanda. OPM ditumbuhkan dan dibesarkan oleh seluruh proses yang di dalamnya tersimpan pengalaman ketidakadilan oleh rekayasa berlebihan dari militer Indonesia. Sebagian elit Papua pimpinan OPM membangun perlawanan. Sejak itu para elit Papua ini mencoba melibatkan rakyat dalam usahanya "merebut kembali" kemerdekaan Papua Barat yang sempat mereka proklamasikan pada 1 Desember 1961. ${ }^{17}$

Gerakan ini sebenarnya menjadi hal yang dikhawatirkan oleh Pemerintah. Karena kegiatan-kegiatan kelompok ini dapat menyebabkan dibatalkannya keabsahan Penentuan Pendapat Rakyat (Pepera) 1969, yaitu referendum yang digelar dibawah pengawasan PBB yang membuat Papua menjadi bagian dari Indonesia. Kekhawatiran ini menyebabkan pemakaian kekuatan yang berlebihan terhadap aksi-aksi Pro-Kemerdekaan, sanksi keras terhadap penggunaan simbol-simbol kemerdekaan seperti pengibaran bendera Bintang Kejora, penyiksaan dan perlakuan semena-mena terhadap orang-orang yang dicurigai sebagai aktivis pro-kemerdekaan, pengawasan terhdap kelomok-kelompok sipil yang aktif secara politik, pembentukan institusi paralel untuk menandingi dan memperlemah kelompok-kelompok masyarakat, dan pembatasan ketat terhadap akses Internasional ke Papua.

\section{d. Sikap Anti Pendatang Istilah}

"Pendatang" di Papua mengacu pada berbagai kelompok orang nonPapua yang seringkali digambarkan sebagai si "rambut lurus" atau si "kulit terang". Paralel dengan dominasi isu "M", teror dan intimidasi terhadap pendatang meningkat. Sejumlah pemerasan dilakukan oleh Satuan Tugas (Satgas) Papua yang juga tak dapat terkontrol sepenuhnya oleh Presidium Dewan Papua. Potensi konflik horizontal menganga terbuka. Beberapa kali terjadi kekerasan antara keduanya terutama antara orang Papua asli dengan kelompok pendatang yang disebut BBM (Bugis, Buton, dan Makasar). Selain belum berkembangnya pemikiran PDP tentang posisi pendatang,

\footnotetext{
${ }^{17}$ Robin Osborne, 1986, "OPM and the quest for West Papuan unity”, dalam R.J. May (ed.) Between two nations, Australia: Robert Brown and Associates, hlm. 51-53.
} 
kalangan pendatang pun tidak memiliki lembaga representasi yang memadai. ${ }^{18}$

Bila pun ada, seperti KSS (Kerukunan Keluarga Sulawesi Selatan) oleh orang Papua lebih dipandang sebagai lembaga korporatif yang dekat dengan militer dan pemerintah. ${ }^{19}$ Selain KSS, belum ditemukan asosiasi pendatang yang berupaya meningkatkan posisi tawar dan kualitas representasinya dihadapan militer, pemerintah, maupun penduduk asli. Hingga 2001 belum terlihat upaya rekonsiliasi dan negosiasi antara kelompok pribumi Papua dengan pendatang. Sebagian besar pendatang dicekam ketakutan, ketidakpastian masa depan, dan terbatasnya pilihanpilihan. Pendatang pun sebagian berpikir untuk dan sebagian lainnya sudah meninggalkan tanah Papua. Tetapi mereka yang merasa terdesak dan harus mempertahankan diri mencoba mempersenjatai diri dengan senjata rakitan yang lebih efektif untuk membunuh dibandingkan dengan senjata orang Papua semacam parang, tombak, atau panah. Reaksi ini justru meningkatkan lingkaran kekerasan di Papua. Ketegangan hubungan pendatang-pribumi berada pada titik terburuk. Pembantaian pendatang oleh orang Dani pada Oktober 2000 di Wamena merupakan penegasan atas ketegangan itu.

Keadaan menjadi lebih buruk bagi transmigran karena mereka menjadi korban di dalam pertarungan OPM melawan militer Indonesia. Transmigran di Arso, Jayapura, adalah contoh di mana transmigran menjadi bulan-bulanan di tengah konflik dan pertarungan politik. Kasus transmigran Satuan Pemukiman (SP) 7 dan SP 8 Bonggo Jayapura yang meninggalkan lokasi karena teror dan mengungsi ke LBH Jayapura menjadi puncak gunung es dari problem transmigrasi di Papua. Sejak Januari 1999 hingga pertengahan 2001 mereka terlantar, tidak mendapat perhatian. Akibatnya

${ }^{18}$ Secara berimbang pada 1986 Aditjondromenguraikan dampak negatif dan positif dari kehadiran migran asal Sulawesi di Papua (waktu itu disebut Irian Jaya). Lihat George Y. Aditjondro, "Suatu Telaah Dampak Migrasi Suku-suku Bangsa dari Sulawesi Selatan dan Tenggara ke Irian Jaya" Laporan Seminar Pengembangan SDM di Irian Jaya (Jakarta: LRKN LIPI) hlm. 26-47.

${ }^{19}$ Pendatang pada umumnya secara politik lebih dinilai berpihak pada penguasa. Dalam setiap krisis politik yang menghadapkan pemerintah versus penduduk asli, posisi pendatang ditempatkan berseberangan dengan penduduk asli. Pada Kerusuhan 1996 di Abepura isu utamanya adalah pengiriman jenazah Thomas Wanggai dan kemarahan orang Papua pada aparat keamanan namun pendatang di Abepura, Waena, dan Sentani menjadi sasaran kekerasan. Pada sisi ini dapat dikatakan pendatang menjadi korban. Tindakan KSS membuat demo tandingan mengecam dan menantang orang Papua di Sorong dan Manokwari pada 1998 adalah contoh lain dari keberpihakan pendatang pada militer. Pada sisi ini dapat dilihat tindakan pendatang yang memupuk kebencian orang Papua terhadap pendatang. [Lihat paper: Muridan S. Widjojo, Di Antara Kebutuhan Demokrasi dan Kemenangan Politik Kekerasan; Konflik Papua Pasca Orde Baru, (Jakarta: Lembaga Ilmu Pengetahuan Indonesia, LP3ES dan The Ford Foundation, 2001). 
selama mengungsi sudah 22 orang meninggal karena berbagai penyakit. ${ }^{20}$ Bagi OPM transmigran merupakan target yang paling mudah untuk melakukan tekanan terhadap Pemerintah RI dan militer. Bagi militer, transmigran yang terancam dapat menjadi dalih yang efektif untuk membangun citra Papua sebagai wilayah yang rawan dan tidak stabil dari segi keamanan.

\section{Dampak Konflik Terhadap Kehidupan Masyarakat Papua}

Ada beberapa dampak yang ditimbulkan akibat adanya konflik yang berkepanjangan terhadap kehidupan masyakarat Papua. Di antaranya adalah:

\section{a. Birokrasi Pemerintahan Menjadi Lumpuh}

Dengan adanya banyak konflik dan kekerasan yang terjadi maka berakibat pada ketidakdisiplinan birokrat. Kantor-kantor Pemda Tingkat I misalnya lebih banyak terlihat kosong. Pada awal 2000, Kompas melaporkan absensi yang tinggi di kalangan pejabatnya. Mulai dari Gubernur, para kepala kantor wilayah, dan kepala dinas sangat sering meninggalkan kantor dan lebih banyak melakukan perjalanan ke Jakarta. Tugas-tugas pelayanan publik pun semakin terbengkalai. Warga yang berkepentingan pun akhirnya tidak terlayani. Padahal warga-warga tersebut tidak hanya datang dari sekitar Jayapura tetapi juga dari kabupaten lain dengan ongkos transport pesawat yang mahal. ${ }^{21}$ Hal ini juga terjadi di pedalaman, banyak kantor-kantor kecamatan yang kosong dari pejabat birokrasi.

Ketika ditelusuri, maka penyebab utama yang menjadi faktor penekan tidak lain karena kondisi keamanan bagi pejabat pemerintah daerah, sehingga mereka lebih memilih meninggalkan tugas sambil menyelamatkan diri dan posisi. Akibatnya, masyarakat Papua tidak mendapat pelayanan yang maksimal dari birokrat sebagaimana pada daerah-daerah lain di Indonesia.

\section{b. Timbulnya Provokasi Berdasarkan Agama}

Adanya konflik berkepanjangan di Papua juga menjadikan agama sebagai objek provokasi. Provokasi ke arah kekerasan dengan bendera suku

\footnotetext{
20“"Jenazah Kopral diusung ke DPRD Papua,” Kompas, 22 Juli 2000.

${ }^{21}$ Lihat "Ketika Papua Ditinggalkan Pimpinan,” Kompas, 31 Januari 2000. Di dalam laporan ini dikutip pula pendapat Saul J Bonay, bekas komandan OPM, yang juga bekas narapidana di LP Kalisosok bahwa kinerja kerja pemerintah sekarang mendorong tuntutan merdeka semakin kuat. Pengibaran bendera bintang kejora pun semakin gencar dilakukan secara sporadis di mana-mana. Kehadiran pemerintah di Papua hanya untuk mengejar kepentingan pribadi dan keluarga. Tidak ada upaya membangun kesejahteraan rakyat. Jika ada, ujungujungnya adalah korupsi, kolusi, dan nepotisme.
} 
bangsa maupun agama secara kronologis memang paralel dengan pembalikan isu politik dari HAM dan demokratisasi ke separatisme. Versi I yang ditujukan kepada umat Muslim bahwa kaum Kristen akan melakukan pembakaran masjid. Sebaliknya Versi II yang ditujukan kepada kaum Kristen menyatakan bahwa pihak Islam akan melakukan pembakaran gereja. Selebaran beredar tiga hari setelah demo besar di gedung DPRD I menuntut penarikan pasukan TNI dari Papua. ${ }^{22}$ Provokasi tersebut tidak berhasil karena diantisipasi dengan cepat oleh para pemimpin dan tokoh agama. ${ }^{23}$

\section{c. Timbulnya Semangat Papuanisasi}

Konflik berkepanjangan antara pendatang dengan warga asli Papua, antara pemerintah pusat dengan pemuka suku, termasuk aparat keamanan dengan milisi OPM mengakibatkan timbulnya semangat baru Papuanisasi. Semangat akan adanya satu kesatuan sebagai bangsa Papua, dan satu kesatuan sebagai bangsa yang mengalami kolonialistik dari pemerintah Indonesia.

Semangat ini kembali muncul saat pemerintah menggalakan gerakan transmigrasi, dengan melakukan penyebaran penduduk luar ke wilayahwilayah Papua. ${ }^{24}$ Selain itu adanya stigma "jawanisasi" terhadap wilayah Papua, sebagai wujud penguasaan orang jawa terhadap Papua.

Wacana Papuanisasi juga berujung pada tuntutan duduknya putra daerah Papua sebagai pimpinan pemerintahan daerah, sehingga diharapkan adanya komitmen dan strategi baru pembangunan yang lebih mengutamakan warga Papua secara keseluruhan.

\footnotetext{
${ }^{22}$ Tanda provokasi ini ditemukan saat beredar dua versi selebaran di Jayapura pada SeninSelasa, 8-9 Juni 1998, pada saat isu HAM dan demokrasi sedang memuncak di Papua.

${ }^{23}$ Walaupun provokasi berdasarkan agama dapat diredam, tetapi kekerasan sebagaimana biasa tetap terjadi. Terlihat sembilan hari pasca munculnya selebaran tepatnya tanggal 17 Juni 1998, kekerasan terjadi di tempat lain dengan korban nyawa tiga warga transmigran Arso dan seorang diculik. Menarik bahwa kemudian pada hari yang sama TNI AD menuduh OPM. Kekerasan kemudian terjadi di kampus Uncen antara massa mahasiswa melawan aparat kepolisian dan TNI pada 3 Juli ketika berlangsung demo pro Papua Merdeka. Seorang mahasiswa tewas tertembak, seorang anak kecil tewas terkena peluru nyasar, dan seorang aparat intel dianiaya. Kekerasan yang paling menonjol pada 1998 adalah bentrok antara massa pro Papua Merdeka melawan aparat keamanan. Jumlah korban kekerasan selama 1998 tidak menonjol, "hanya" 9 orang tewas dan 69 luka-luka. Namun pada 1998 ini atmosfer kekerasan sudah sangat terasa. Meskipun jumlah korban tewas hanya 9 orang tetapi terjadi secara merata di Jayapura, Biak, Sorong, Tembagapura, Timika, dan Manokwari. Ketegangan yang dihasilkan oleh kekerasan itu mencolok karena isu yang muncul adalah Papua Merdeka dan isu anti pendatang di kalangan orang Papua.

${ }^{24}$ Sikap anti transmigrasi tidak hanya melanda kalangan Intelektual Papua, tetapi juga kalangan birokrat dan anggota DPRD I Irian Jaya yang orang asli Papua. [Lihat: "Jenazah Kopral diusung ke DPRD Papua", Kompas Online, 21/7/2000.
} 


\section{d. Munculnya Istilah $\mathrm{M}(\mathbf{M}=$ Merdeka)}

Rentetan konflik dan kekerasan yang terjadi di Papua juga menimbulkan gagasan disintegrasi bangsa di kalangan pejabat DPRP. Walaupun gagasan ini tidak disampaikan secara langsung, tetapi penggunaan Istilah $\mathrm{M}$ lebih sering dilontarkan dalam momen-momen tertentu dalam diskusi publik dan pemerintahan.

Istilah ini muncul menjelang Dialog Nasional 1999 antara Tim 100 delegasi Papua dengan Presiden BJ Habibie. Ketika Forum Rekonsiliasi Rakyat Irian Jaya (Foreri) didirikan, perdebatan antara pilihan Otonomi (O), Federasi (F), dan Merdeka (M), pada awalnya masih terbuka. Namun setelah dialog nasional, isu pilihan ini menjadi dominan. Otokritik dari sesama Papua terhadap eforia M selalu dicurigai. Setiap upaya itu, lalu diberikan stigma "otonomi". Sebagian kelompok Pro-Demokrasi kemudian menyesuaikan diri dan mencoba mendukung aspirasi "M". Sebagian mencoba diam dan menjaga jarak. Dengan demikian, dominasi faksi di dalam masyarakat yang mendukung $M$ menjadi sangat dominan. Simbol huruf " $F$ " yang sebelumnya berarti "Federasi" tenggelam dengan sendirinya. Orang dalam kehidupan sehari-hari dengan mudah membuat dikotomi "O" dan "M". ${ }^{25}$

\section{Optimalisasi Otonomi Khusus Papua}

Otonomi Khusus Papua yang telah diberlakukan pada hakikatnya diniatkan sebagai obat penenang konflik dan polemik yang bergejolak di Papua saat ini. Akan tetapi dalam realitanya ternyata pelaksanaan otonomi khusus belum maksimal, bahkan dinilai gagal. Sebagaimana pendapat anggota Majelis Rakyat Papua ${ }^{26}$, karena UU No. 21 tahun 2001 memerintahkan pemerintah membuat peraturan namun tidak dilaksanakan. Selain itu, Pemerintah Pusat telah menggulirkan UU No. 45 tahun 1999 tentang pembentukan Provinsi Papua Barat dan Papua Tengah, walaupun akhirnya Papua Tengah dibatalkan oleh Mahkamah Konstitusi.

Oleh karenanya, Otonomi Khusus yang diharapkan menjadi obat penenang, hendaknya mampu melakukan optimalisasi dalam beberapa hal. Sehingga konflik, polemik, dan ragam kekerasan yang terjadi dapat benarbenar terhenti, dan harapan masyarakat Papua menjadi masyarakat yang makmur dan sejahtera dapat terwujud dengan maksimal. Adapun optimalisasi otonomi khusus Papua yang dapat dilakukan di antaranya adalah:

\footnotetext{
${ }^{25}$ Lihat paper: Muridan S. Widjojo, Di Antara Kebutuhan Demokrasi dan Kemenangan Politik Kekerasan; Konflik Papua Pasca Orde Baru, (Jakarta: Lembaga Ilmu Pengetahuan Indonesia, LP3ES dan The Ford Foundation, 2001).

${ }^{26}$ Lihat: Riris Katharina, Implementasi Otonomi Khusus di Provinsi Papua, hlm. 33
} 


\section{a. Optimalisasi Keberpihakan Pemerintah Pusat terhadap Pelaksanaan Otsus}

Ketidakberpihakan pemerintah pusat kepada Otsus Papua dapat dinilai setidaknya dari hal sebagai berikut, seperti; lahirnya Inpres Nomor 1 Tahun 2003 tentang Percepatan Pelaksanaan Pemekaran Provinsi Irian Jaya sesuai dengan UU No. 45 Tahun 1999 tentang Pembentukan Provinsi Irian Jaya Tengah, Papua Barat, Kabupaten Paniai, Kabupaten Mimika, Kabupaten Puncak Jaya, dan Kota Sorong. Lahirnya Inpres ini dinilai telah memunculkan ketidakpastian hukum serta kebingungan bagi pejabat publik baik di provinsi maupun di kabupaten/kota dalam penyelenggaraan pemerintahan, khususnya dalam menjalankan UU Otsus Papua. Kekecewaan lainnya berakar dari inkonsistensi kebijakan pemerintah pusat terhadap Papua, di antaranya pemekaran wilayah di Papua, termasuk di dalamnya masalah dilantikkan Majelis Rakyat Papua Irian Jaya Barat.

Walaupun akhirya Undang-Undang Nomor 45 Tahun 1999 tentang Pembentukkan Provinsi Irian Jaya Tengah, Provinsi Irian Jaya Barat, Kabupaten Paniai, Kabupaten Mimika, Kabupaten Puncak Jaya, dan Kota Sorong kemudian dibatalkan dengan keputusan Sidang Pleno Mahkamah Konstitusi pada 11 November $2004{ }^{27}$

Kebijakan pemerintah ini menimbulkan demonstrasi besar-besaran di berbagai kalangan masyarakat Papua. Sehingga berdampak pada perbuatan anarkis dan kekerasan, yang tentunya yang menjadi korban adalah aparat keamanan dan penduduk pendatang non-papua. Aksi besar-besaran ini direspon oleh DPRD Provinsi Irian Jaya (kini Provinsi Papua) dengan mengeluarkan Keputusan DPRD No. 11/DPRD/1999 tentang Pernyataan Pendapat DPRD Provinsi Irian Jaya kepada Pemerintah Pusat untuk Menolak Pemekaran Provinsi Irian Jaya dan Usul Pencabutan Surat Keputusan Presiden RI No. 327/M 1999 tertanggal 5 Oktober 1999. Oleh karenanya, optimalisasi yang diperlukan adalah keberpihakan pemerintah pusat terhadap aspirasi dan keinginan masyarakat Papua guna mewujudkan niat mulia otonomi khusus dari UU No. 21 tahun 2001.

\section{b. Optimalisasi Peran MRP dalam UU Otsus}

Majelis Rakyat Papua merupakan ciri khas dari kekhususan Papua. Berdasarkan Peraturan Pemerintah Nomor 54 Tahun 2004 tentang Majelis

\footnotetext{
${ }^{27}$ Kebijakan tersebut dianggap inkonsisten karena dalam Penjelasan Umum yang mengakui wilayah Provinsi Papua terdiri atas 12 (dua belas) kabupaten dan 2 (dua) kota, termasuk Kabupaten Paniai, Kabupaten Mimika, Kabupaten Puncak Jaya, Dan Kota Sorong yang dibentuk dengan UU No. 45/1999. Di sisi lain, UU No. 21/2001 tidak menyinggung sedikit pun keberadaan Provinsi Irian Jaya Barat dan Provinsi Irian Jaya Tengah yang juga dibentuk dengan UU No. 45/1999.
} 
Rakyat Papua (selanjutnya disingkat PP No. 54/2004), Majelis Rakyat Papua berperan serta dalam memberikan pertimbangan dan persetujuan dalam perumusan kebijakan daerah, dalam rangka kesetaraan dan keragaman kehidupan masyarakat Papua, melestarikan budaya serta lingkungan alam Papua.

Pasal 1 huruf g UU No. 21 Tahun 2001 menyatakan bahwa MRP adalah representasi kultural orang asli Papua, yang memiliki wewenang tertentu dalam rangka perlindungan hak-hak orang asli Papua dengan berlandaskan pada penghormatan terhadap adat dan budaya, pemberdayaan perempuan, dan pemantapan kerukunan hidup beragama.

Sebagai lembaga representasi kultural, maka pemilihan anggota MRP dilakukan melalui proses yang demokratis dan transparan pada tingkat distrik, kabupaten/kota dan tingkat provinsi untuk memperoleh wakil-wakil dari masyarakat adat, masyarakat agama dan masyarakat perempuan.

Dalam perjalanan pelaksanaan otonomi khusus, MRP yang merupakan representatif dari masyarakat Papua kurang mendapat peran. Bahkan cenderung mengalami reduksi kewenangan. Terlihat dari ketidakjelasan kedudukan MRP sebagai lembaga legislatif atau eksekutif. Sehingga ketika terjadi konflik dan pertikaian, MRP tidak lagi mampu menjadi penengah. Padahal MRP sejatinya dapat menjadi penyambung lidah masyarakat bawah kepada pejabat atas, baik itu gubernur, DPRP, bahkan kepada Pemerintah Pusat. Oleh karenanya, diperlukan optimalisasi peran MRP ini dalam ranah otonomi khusus Papua, sehingga kedamaian dan ketentraman dapat terwujud.

\section{c. Optimalisasi Pengawasan Dana Otonomi Khusus}

Berdasarkan Pasal 4 ayat (5) Peraturan Tata Tertib DPRP, fungsi pengawasan DPRP diwujudkan dalam bentuk pengawasan terhadap pelaksanaan undang-undang, peraturan pemerintah, peraturan presiden, perdasi dan perdasus, peraturan gubernur, keputusan gubernur, dan kebijakan yang ditetapkan oleh pemerintah daerah.

Pengawasan dana Otsus pun dinilai sulit dilakukan oleh anggota DPRP. Hal ini disebabkan karena laporan pertanggungjawaban APBD dibuat menurut ketentuan dalam Permendagri. ${ }^{28}$ Padahal, seharusnya dana APBD menggunakan Kebijakan Umum Anggaran (KUA) yang ada selama ini, dan dana Otsus menggunakan Kebijakan Khusus Anggaran (KA) yang

\footnotetext{
${ }^{28}$ Yaitu Permendagri No. 13 Tahun 2006 tentang Pedoman Pengelolaan Keuangan Daerah sebagaimana telah diubah dengan Peraturan Menteri Dalam Negeri Nomor 59 Tahun 2007 tentang Perubahan atas Peraturan Menteri Dalam Negeri Nomor 13 Tahun 2006 tentang Pedoman Pengelolaan Keuangan Daerah dan Permendagri No. 21 Tahun 2001 tentang Perubahan Kedua Atas Permendagri No. 13 Tahun 2006.
} 
seharusnya dibuat tersendiri. Kebijakan khusus ini nantinya merupakan penjabaran dari program-program yang bersifat khusus yang diperintahkan oleh UU Otsus Papua.

Oleh karenanya, diperlukan optimalisasi pengawasan dana Otsus Papua, agar tidak disalahgunakan oleh kalangan tertentu, sehingga kesejahteraan tidak menyerap pada lapisan bawah masyarakat.

Pada dasarnya masih banyak upaya optimalisasi yang harus dilakukan terhadap penerapan otonomi khusus Papua, karena tetap diyakini bahwa pemberian otonomi khusus merupakan upaya akhir dari pemerintah Republik Indonesia untuk tetap mempertahankan tanah Papua sebagai bagian dari wilayah NKRI.

\section{Penutup}

Kekerasan, konflik, sengketa, polemik, kontak senjata, dan pertumpahan darah masih selalu mewarnai dalam kehidupan masyarakat Papua. Seolah hal ini bagian dari ajang unjuk gigi dari pihak berkepentingan untuk menunjukan bahwa Papua masih belum tenteram berada di bawah negara Republik Indonesia. Tantangan yang dihadapi oleh pemerintah adalah menemukan sebuah strategi jangka pendek yang dapat mengurangi kekerasan sambil terus mencari kebijakan yang dapat membawa manfaat sosial, ekonomi, dan politik jangka panjang dan menangani ketidakpuasan yang sudah lama dirasakan oleh masyarakat Papua. Strategi tersebut harus melibatkan perubahan-perubahan yang jelas dan nyata dalam pengawasan, kontrol, dan akuntabilitas terhadap seluruh komponen pelaksana di lapangan.

Termasuk pihak keamanan, dalam hal ini polisi dan tentara yang selalu disalahkan karena dianggap sebagai pelaku kekerasan, padahal banyak juga dari mereka yang menjadi korban. Akan tetapi, pihak keamanan menjadi simbol atas segala sesuatu yang salah dengan penanganan Pemerintah Pusat terhadap Papua. Karena itu, sebuah perubahan dalam kebijakan keamanan menyodorkan harapan paling baik dari sebuah "Quick Win" yang dapat memperbaiki dinamika politik dan menghentikan Papua merosot ke arah kekerasan lebih lanjut.

Oleh karenanya, kepada pemerintah Indonesia hendaknya lebih mengembangkan sebuah mekanisme pembuatan kebijakan yang lebih terintegrasi mengenai Papua di tingkat nasional dan provinsi untuk menjamin keberlangsungan program-program yang telah dirancang untuk memberikan manfaat-manfaat konkret bagi rakyat Papua dan membangun kepercayaan tidak diperlemah secara tidak sengaja oleh keputusan-keputusan atau tindakan-tindakan yang diambil pemerintah pusat. Selain itu, adanya mekanisme pelaporan keamanan yang lebih terpadu, serta pengawasan yang ketat tidak hanya terbatas pada pembangunan tetapi juga mencakup 
kebijakan keamanan, termasuk audit yang rutin dan independen terhadap penghasilan aparat keamanan dari kegiatan di Papua.

\section{Daftar Pustaka}

\section{A. Buku}

Budiardjo, Carmel, dan Liem Soei Liong, West Papua: The Obliteration of a People, London: Tapol.

Djojosoekarto, Agung, dkk., 2008. Kinerja Otonomi Khusus, Jakarta: Kemitraan.

Koentjaraningrat, 1993. Irian Jaya: Membangun Masyarakat Majemuk, Jakarta: Djambatan.

Mansoben, Johszua, Sistem Politik Tradisional di Irian Jaya, Jakarta-Leiden: LIPI-RUL.

Musa'ad, Mohammad A., "Kontekstualisasi Pelaksanaan Otonomi Khusus di Provinsi Papua: Perspektif Struktur dan Kewenangan Pemerintahan", Jurnal Kajian, Vol, 16, No, 2, Juni 2011, Jakarta: Sekretariat Jenderal DPR RI.

Nawawi, Hadari, 1994. Metode Penelitian Ilmiah, Jakarta: Rineka Cipta.

Osborne, Robin, 1986. "OPM and the quest for West Papuan unity", dalam R,J, May (ed.) Between two nations, Australia: Robert Brown and Associates.

Pigay, Decki Natalis, 2000. Evolusi Nasionalisme dan Sejarah Konflik Politik di Papua, Jakarta: Sinar Harapan.

Widjojo, Muridan S., 2001. Di Antara Kebutuhan Demokrasi dan Kemenangan Politik Kekerasan; Konflik Papua Pasca Orde Baru, Jakarta: Lembaga Ilmu Pengetahuan Indonesia, LP3ES dan The Ford Foundation.

\section{B. Media Massa}

"Jenazah Kopral diusung ke DPRD Papua," Kompas, 22 Juli 2000.

"Ketika Papua Ditinggalkan Pimpinan," Kompas, 31 Januari 2000.

"Membangun Papua: Dari Otsus "Terbitlah" UP4B, Kompas, 4 November 2011.

Piliang, Indra J., Otonomi Khusus Papua dan MRP, Suara Pembaruan, 11 Juli 2003.

Saleh, M. Ridha, "Saudara Presiden, Datanglah ke Papua, Kompas, 3 November 2011. 


\section{Lain-lain}

Aditjondro, George Y., "Suatu Telaah Dampak Migrasi Suku-suku Bangsa dari Sulawesi Selatan dan Tenggara ke Irian Jaya" Laporan Seminar Pengembangan SDM di Irian Jaya, Jakarta: LRKN LIPI.

Asia Report N 232, Indonesia, Dinamika Kekerasan di Papua, Jakarta: International Crisis Group, 2012.

Katharina, Riris, Implementasi Otonomi Khusus di Provinsi Papua, makalah Tim Peneliti DPR RI. 